\title{
The response of the sugar beet (Beta vulgaris L.ssp. vulgaris var. altissima Döll) genotypes to heat stress in initial growth stage
}

\author{
Mohammad MALMIR ${ }^{1}$, Rahim MOHAMMADIAN ${ }^{2,3}$, Ali SOROOSHZADEH ${ }^{1,3}$, Ali MOKHTASSI- \\ BIDGOLI $^{1}$, Somayeh EHSANFAR ${ }^{1}$
}

Received November 28, 2018; accepted January 2, 2020. Delo je prispelo 28. novembra 2018, sprejeto 2. januarja 2020.

The response of the sugar beet (Beta vulgaris L.ssp. vulgaris var. altissima Döll) genotypes to heat stress in initial growth stage

Abstract: The continuous trend of global warming and increasing interest toward cultivating sugar beet (Beta vulgaris L. ssp. vulgaris var. altissima Döll) in tropical regions led us to conduct this study to investigate the effect of high temperature on sugar beet at initial growth stages. Thirty one genotypes were incubated at two temperatures $\left(20{ }^{\circ} \mathrm{C}\right.$ and $30{ }^{\circ} \mathrm{C}$ ) in laboratory for germination test. The same genotypes were assessed for physiological parameters at $30{ }^{\circ} \mathrm{C}$ in greenhouse, too. Increasing temperature decreased germination indices with a high variability among the genotypes. Seed vigor index and seminal root length were decreased higher than other indices. The genotypes with higher greenness index had higher total dry mass, leaf area and leaf temperature depression $(L T D)$, and those with higher seed vigor index indicated great quantum efficiency of PSII ( Fv/Fm) values. 'S1-92521' produced high records in both laboratory and greenhouse experiments. Although 'S1-92521' showed good tolerance in both laboratory and greenhouse experiments, totally, sugar beet genotypes had different performance at two experiments. According to the results, seed vigor index could be used as a screening tool in laboratory, and LTD and Fv/Fm were considered as good criteria for screening heat-tolerant genotypes in greenhouse.

Key words: genotype screening; heat stress; leaf temperature depression; Fv/Fm; seed vigor index
Odziv genotipov sladkorne pese (Beta vulgaris L. ssp. vulgaris var. altissima Döll) na vročinski stres v začetnih fazah rasti

Izvleček: Naraščajoči trend globalnega segrevanja in vse večji interes za gojenje sladkorne pese (Beta vulgaris L. ssp. vulgaris var. altissima Döll) v tropskih območjih so privedli $\mathrm{k}$ izvedbi te raziskave, $\mathrm{v}$ kateri je bil preučevan učinek visokih temperature na sladkorno peso $\mathrm{v}$ začetnih fazah rasti. 31 genotipov je bilo inkubiranih pri dveh temperaturah $\left(20^{\circ} \mathrm{C}\right.$ in $30^{\circ} \mathrm{C}$ ) v laboratoriju za kalitvene teste. $\mathrm{Na}$ istih genotipih so bili v rastlinjaku ocenjeni fiziološki parametri pri temperaturi $30{ }^{\circ} \mathrm{C}$ Povišanje temperature je zmanjšalo indekse kalitve $\mathrm{z}$ veliko spremenljivostjo med genotipi. Indeks vitalnosti semen in dolžina semenske korenine sta se bolj zmanjšala kot drugi indeksi. Genotipi z večjimi indeksi zelenosti so imeli večjo celokupno suho maso, večjo listno površino in večji upad temperature listov $(L T D)$, genotipi $\mathrm{z}$ večjimi indeksi vitalnosti semen so pokazali velike vrednosti kvantne učinkovitosti PSII $(F v / F m)$. 'S1-92521'je imel velike vrednosti vseh merjenih parametrov tako v laboratoriju kot v rastlinjaku. Čeprav je imel genotip 'S1-92521' dobro tolerance na visoke temperature tako v laboratoriju kot v rastlinjaku, so imeli drugi genotipi sladkorne pese zelo različne odzive $\mathrm{v}$ obeh poskusih. Glede na rezultate bi lahko indeks vitalnosti semen uporabili kot primerno orodje za preiskušanje genotipov v laboratoriju, parametra $L T D$ in $F v / F m$ pa sta se izkazala kot dober kriterij za preiskušanje genotipov na visoke temperature v rastlinjaku.

Ključne besede: preiskus genotipov; vročinski stres; upad listne temperature; $F v / F m$; indeks vitalnosti semen

1 Tarbiat Modares University, Faculty of Agriculture, Department of Agronomy, Tehran, Iran

2 Sugar Beet Seed Institute, Agricultural Research, Education and Extension Organization (AREEO), Karaj, Iran

3 Corresponding author, e-mail: r_mohammadian@hotmail.com, soroosh@modares.ac.ir 


\section{INTRODUCTION}

Production of sugar beet (Beta vulgaris L. ssp. vulgaris var. altissima Döll) is often limited by environmental conditions including insufficient water, heat, freezing temperatures and salinity. These conditions lead to decreasing the rates of photosynthesis and canopy expansion (Yang et al., 2017; Zandalinas et al., 2018). Unfortunately, global warming has caused a rise in the world's temperature, and changed the climate in many areas of the world including regions with sugar beet plantations. However, if some genotypes of sugar beet can be proved to be tolerant to high temperature, cultivation of this plant will be less limited due to the climate change. So, there is an interest in summer cultivation of sugar beet and cultivation of sugar beet in tropical regions (El-Kholi, 2008; Ober \& Rajabi, 2010). In addition, maximum temperature in semi-arid regions makes it urgent to breed cultivars for high temperature conditions (Karandish et al., 2017). However, there has not been much research and development on heat stress tolerance in this crop.

Seed germination is one of the crop's characteristics that can be used to assess its establishment in field. Physiological processes in germination influence plant metabolism and performance in later stages are mostly affected by abiotic stresses (Gratani et al., 2000; Liu and Huang, 2008; Wang et al., 2008; Silva et al., 2010). High temperature declines germination as well as seedling growth and survival (Beckage \& Clark, 2003; Arx von et al., 2013; Fahad et al., 2017). Seed viability and vigor directly affect the performance of seeds and vegetative growth that finally determine the crop yield (TeKrony \& Egli, 1991). Seed vigor determines the potential of a rapid and uniform emergence and development of normal seedlings under field conditions (Baalbaki et al., 2009).

It has been proved that heat tolerance at germination time is positively correlated with later growth phases in cotton (Ashraf et al., 1994). However, there are no information about screening criteria of sugar beet genotypes under high temperature, and also the correlation of tolerance at germination time with growth in later growth stages. Biological process such as photosynthesis, is the most sensitive process that is influenced by high temperature (Buchner et al., 2015; Marias et al., 2017). High temperature induces inhibition of photosynthesis, especially PSII activity through declining electron transport activity (Havaux, 1993; Murakami et al., 2000). The quantum efficiency of PSII $(F v / F m)$ which represents plant nutrient and health status is related to chlorophyll concentration (Mohammadian et al., 2003; Kumar et al., 2017), and has a positive relationship with $\mathrm{CO}_{2}$ fixation and dry matter production (Sharma et al., 2015). In addition, greenness index and dry mass are important when plants are screened for heat tolerance (Joshi et al., 2007; Nagar et al., 2015; Zhou et al., 2015).

Stomata have a vital role in plant cycle due to $\mathrm{CO}_{2}$ and water vapor exchange between plant and atmosphere (Miner et al., 2017). Stomata closure and increasing leaf temperature are happening under high temperatures (Rizhsky et al., 2002; Zandalinas et al., 2018) and drought stress (Mohammadian et al., 2003). Canopy temperature with a potential to be a tool for indirect selection of tolerant genotypes to drought and heat (Reynolds et al., 2009) is consistently negatively correlated with yield (Reynolds et al., 1994; Gutierrez et al., 2010; Pinto et al., 2010), and leaf temperature depression (LTD) represents the plant water status (Mohammadian et al., 2001; Balota et al., 2008; Webber et al., 2017).

Early growth stages of plants are important, because a good seedling establishment leads to a better growth and leaf expanding in later stages of growth. As the canopy is responsible for getting the sun light which is necessary for photosynthesis, the sooner a plant canopy is constructed, the more yield the plant will produce (Mohammadian et al., 2005). Early growth stages are more sensitive to abiotic stresses than the other stages as they have an important role in plant adaptation and can be used for germplasm screening (Munns \& Tester, 2008; Carpýcý et al., 2009; Pandey \& Penna, 2017; Shelke et al., 2017). Screening of genotypes tolerant to specific stresses at early growth stages is rapid, inexpensive and less laborious (Grzesiak et al., 2003; Bafeel, 2014).

There are researches on combined effects of heat and drought stress on sugar beet, but the effect of heat stress, alone, on sugar beet has not been investigated yet. Furthermore, researches lack any study on differences among sugar beet genotypes with regard to heat tolerance. So, this study aimed to investigate the followings by using parameters that are changed under the influence of heat stress: (1) assessing the effect of high temperature on some sugar beet genotypes at germination and seedling establishment stages, (2) determining if genotypes which were tolerant to high temperature in laboratory are heattolerant in greenhouse as well and (3) identifying reliable tools for screening tolerant genotypes in heat stress conditions.

\section{MATERIAL AND METHODS}

This study was conducted in 2015 at Sugar Beet Seed Institute (SBSI), Karaj, Iran. A fundamental germination test was conducted by four sugar beet (Beta vulgaris $\mathrm{L}$. ssp. vulgaris var. altissima Döll) cultivars (Aria, Paya, FD415 and Rosaflor) at nine constant temperatures (20,23, $26,29,32,35,38,41$ and 44 ) in order to determine a tem- 
perature that can affect the growth of sugar beet. Results of this experiment showed that germination percentage and seed vigor index of these cultivars decreased severely at 30(data are not shown in this article). In addition, average temperature of the hottest month of Iran, July, in regions of spring cultivation of sugar beet is around 30 . Based on these two reasons, 30 was selected as a temperature suitable for screening sugar beet genotypes under high temperature. This stage was followed by laboratory and greenhouse experiments using some sugar beet gen- otypes which were selected in a way that they were genetically different (different origins) as much as possible.

\subsection{LABORATORY EXPERIMENT}

This experiment was conducted as factorial in a completely randomized design with four replications. The experimental factors included 31 genotypes of sugar beet and two constant temperatures (20, as control, and 30). Characteristics of the genotypes are

Table 1: Properties of used sugar beet genotypes

\begin{tabular}{|c|c|c|c|c|c|}
\hline Genotype & Poloidy & Monogerm/ MultIgerm & Origin & Characteristic & Resistance/Tolerance to \\
\hline 419 & Diploid & Monogerm & Iran & O-type & - \\
\hline 7112 & Diploid & Monogerm & Iran & O-type & - \\
\hline 31714 & Diploid & Monogerm & Iran & O-type & Rhizomania \\
\hline $110-7-8$ & Diploid & Multigerm & Iran & Half-sib & Drought stress \\
\hline $111-52-25$ & Diploid & Multigerm & Iran & Half-sib & Drought stress \\
\hline S1-92685 & Diploid & Multigerm & Iran & Inbred line & Rhizomania \\
\hline S1-92747 & Diploid & Multigerm & Iran & Inbred line & Rhizomania- Beet cyst nematode \\
\hline S1-92748 & Diploid & Multigerm & Iran & Inbred line & Rhizomania- Beet cyst nematode \\
\hline S1-92749 & Diploid & Multigerm & Iran & Inbred line & Rhizomania- Beet cyst nematode \\
\hline S1-92750 & Diploid & Multigerm & Iran & Inbred line & Rhizomania- Beet cyst nematode \\
\hline S1-92751 & Diploid & Multigerm & Iran & Inbred line & Rhizomania- Beet cyst nematode \\
\hline SB27-H-1 & Diploid & Multigerm & Iran & Half-sib & Rhizomania- Beet cyst nematode \\
\hline SB27-H-2 & Diploid & Multigerm & Iran & Half-sib & Rhizomania- Beet cyst nematode \\
\hline SB27-H-3 & Diploid & Multigerm & Iran & Half-sib & Rhizomania- Beet cyst nematode \\
\hline SB33-H-1 & Diploid & Multigerm & Iran & Half-sib & Rhizomania- Beet cyst nematode \\
\hline SB33-H-2 & Diploid & Multigerm & Iran & Half-sib & Rhizomania- Beet cyst nematode \\
\hline SB33-H-3 & Diploid & Multigerm & Iran & Half-sib & Rhizomania- Beet cyst nematode \\
\hline S1-92521 & Diploid & Multigerm & Iran & Inbred line & Rhizomania- Rhizoctonia \\
\hline S1-92615 & Diploid & Multigerm & Iran & Inbred line & Rhizomania- Rhizoctonia \\
\hline S1-92006 & Diploid & Multigerm & Iran & Inbred line & Rhizomania- Rhizoctonia \\
\hline S1-92039 & Diploid & Multigerm & Iran & Inbred line & Rhizomania- Rhizoctonia \\
\hline S1-92128 & Diploid & Multigerm & Iran & Inbred line & Rhizomania- Rhizoctonia \\
\hline 7233-P.29 & Diploid & Multigerm & Iran & Pollinator population & Salt stress \\
\hline DR1-HSF14-P.35 & Diploid & Multigerm & Iran & Half-sib & Drought stress \\
\hline Fodder beet & Diploid & Multigerm & Iran & Pollinator population & - \\
\hline O.T 607 & Diploid & Monogerm & Iran & O-type & Cercospora \\
\hline S1-24 & Diploid & Multigerm & Iran & Inbred line & Rhizomania \\
\hline SB26 & Diploid & Multigerm & Iran & Pollinator population & Rhizomania- Beet cyst nematode \\
\hline SB36 & Diploid & Monogerm & Iran & Pollinator population & Rhizomania \\
\hline SHR01-P.12 & Diploid & Multigerm & Iran & Pollinator population & Rhizomania \\
\hline SHR02-P.4 & Diploid & Multigerm & Iran & Pollinator population & Rhizomania \\
\hline
\end{tabular}


shown in Table 1. Sugar beet seeds, provided from SBSI, were washed for four hours based on 2010 edition of International Seed Testing Association (ISTA) instruction (ISTA, 2010). The seeds were then disinfected with Carboxin-Thiram $75 \%$ WP $\left(2 \mathrm{~g} \mathrm{l}^{-1}\right)$. To test the germination indices, fifty seeds, $3.5-5 \mathrm{~mm}$ in diameter, were individually placed between the folds of pleated filter paper sheets code 3014 (Schleicher and Schuell, Dassel, Germany). After placing the seeds, the pleated filter papers were covered with an additional sheet of filter paper and were sprayed by $60 \mathrm{ml}$ of distilled water. Then, they were placed in plastic germination boxes of $20 \times$ $15 \times 7 \mathrm{~cm}$ dimensions $(1 \times \mathrm{w} \times \mathrm{h})$ which were incubated in a dark seed germinator at abovementioned constant temperatures. After 7 days of incubation, germination indices, length of seminal root, shoot and seedling (total length of shoot + seminal root) were measured for normal seedlings. Seed vigor index was calculated based on Eq (1) (Agrawal, 2003).

Seed vigor index $=$ Germination $(\%) \times$ Seedling length $(\mathrm{cm})(1)$

\subsection{GREENHOUSE EXPERIMENT}

This experiment was conducted as completely randomized design with 5-10 replications. All examined genotypes at laboratory experiment, were used in greenhouse experiment. The goal of this experiment was to compare the reaction of sugar beet genotypes to high temperature (30) during early growing stage. It also aimed to investigate if the genotypes which were tolerant to high temperature in laboratory were heattolerant in greenhouse, too. Sugar beet seeds were sown in plastic pots of $2015 \mathrm{~cm}$ (h d) dimension filled with farm soil (organic matter $=1.48 \%$; $\mathrm{EC}=1.07 \mathrm{dS} \mathrm{m}^{-1}$ ), and put at a steady temperature (30. The temperature of greenhouse controlled automatically during the experiment. Ten seeds were cultivated in each pot, and the number of seedling emergence was counted when the second leaf appeared. At this stage, all seedlings but one were removed so that just one seedling remained in each pot which continued growing to 4-6 leaves stage. All measurements on the leaves were conducted at 4-6 leaves stage. In order to avoid any changes in leaf temperature, plants were irrigated through drop irrigation whenever needed.

Measurements of photosynthesis and photosynthetic characteristics were performed on third and fourth leaves using a portable photosynthesis system (Li-6400, Li-CorInc, Lincoln, NE., USA) in the open system mode (the leaf chamber was configured to track the temperature, humidity, and illumination conditions of the growth chamber) between 11:00 and 14:00. Data were taken when net photosynthetic rate reached the steady state. Net photosynthetic rate $(A n)$, transpiration rate $(E)$, stomatal conductance $\left(g_{\mathrm{s}}\right)$ and vapor pressure deficit $(V P D)$ were measured on fifth leaves of five replications from each genotypes. Water use efficiency (WUE) was calculated using Eq. (2):

$$
\mathrm{WUE}=\mathrm{An} / \mathrm{E}
$$

Leaf temperature depression (LTD) was calculated from $\mathrm{Eq}$ (3). Air and canopy temperatures were determined using a portable photosynthesis system (Li-6400, Li-Cor Inc, Lincoln, NE., USA).

$$
\text { LTD }\left({ }^{\circ} \mathrm{C}\right)=\text { Leaf temperature }- \text { Air temperature }
$$

Greenness index was measured for the middle part of the third or fourth leaves using SPAD, Minolta SPAD502 chlorophyll meter (Minolta camera Co. Ltd., Osaka, Japan).

The stomatal samples were collected at 30 on a sunny day during 10:00-11:00 am. Samples were taken from the middle parts of adaxial and abaxial surfaces of the third or fourth leaves, at a similar position for all genotypes, after applying a colorless nail polish on the area. For the stomata to be observed clearly by microscope, a transparent nail polish was smeared on the abaxial and adaxial surfaces at the middle of the leaves. The slides of the leaf epidermal fingerprint with the transplant nail polish method (Bin et al., 2008) were observed by an optical microscope (Olympus DP72, Olympus Inc., Japan). The stomatal pore length (SPL), stomatal pore area (SPA) and epidermal cell density $(E C D)$ were measured with Image-Pro Express software (Olympus Inc., Japan). Stomatal density $(S D)$ was calculated using Eq. (4) (Xu \& Zhou, 2005; Xu et al., 2009).

$$
\mathrm{SD}=\text { stomata } /(\text { epidermal cells }+ \text { stomata }) \times 100
$$

The stomatal pore area index (SPAI) is defined as the total stomatal aperture area per unit of leaf area and is calculated from Eq. (5) (Zheng et al., 2013):

SPAI = Stomatal average density $\times$ stomatal pore area per stomata $\times 100$

Chlorophyll fluorescence parameters were assessed using a portable stress meter (Walz GmbH Eichenring, 691090 Effeltrich, Germany). Minimal fluorescence, $F_{0}$, and maximal fluorescence, $F m$, were measured in 30 min dark-adapted leaves. Variable fluorescence ( $F v$ $\left.=F m-F_{0}\right)$ and quantum efficiency of PSII $(F v / F m)$ for 
dark-adapted leaves were calculated as well (Maxwell \& Johnson, 2000).

Each plant was separated into root, leaf and petiole parts after being harvested at 4-6 leave stage (36 days after seeding). Measuring leaf area was done immediately afterwards using a leaf area meter (Delta- T Devices LTD, Burwell, Cambridge, England), followed by measuring fresh and dry mass of the mentioned parts (being dried in an oven at $85^{\circ} \mathrm{C}$ for $48 \mathrm{~h}$ ).

\subsection{DATA ANALYSIS}

The PROC UNIVARIATE within SAS v9.1 software (SAS Institute Inc., Cary, NC, USA) was used for data analysis, and residuals were distributed normally. Significant differences between the means were determined through the least significant difference (LSD) test at the 0.05 probability level. The protected least significant difference (protected LSD) was used to compare the means of main effects for the treatments whose effects were statistically significant at $p<0.01$ or $p<0.05$ as the Ftest indicated. In addition, principal component analysis (PCA) were performed by XLSTAT 2016.

\section{RESULTS}

\subsection{LABORATORY EXPERIMENT}

There was a significant difference between genotypes based on measured traits. As shown in Figure $1 \mathrm{~A}, 15$ genotypes were ranked as susceptible and 'S192521' was the most tolerant to high temperature, regarding seed germination (Figure 1A). Seed vigor index declined as the temperature rose (Figure 1B). With regards to seed vigor index, 24 genotypes were susceptible to high temperature. This trait did not change significantly in four genotypes and increased in three genotypes (S1-92521, SHR01-P.12, and O.T.607) (Figure $1 \mathrm{~B})$. All measured parameters at $20^{\circ} \mathrm{C}$ and $30^{\circ} \mathrm{C}$ are presented in supplemental data (supplementary material, not presented ).

In $83.87 \%$ of sugar beet genotypes, there was a decrease in seminal root length at 30 compared to control (20), while the seminal root length of $6.45 \%$ of genotypes increased and that of $9.68 \%$ of genotypes did not change considerably (Figure 1C). The highest decrease and increase in seminal root length at 30, compared to that at 20, was observed for 'SHR02-P.4' (56.40\%) and 'SHR01-P.12' (13.81\%), respectively (Figure 1C). Genotypes which were not affected by heat stress significantly included S1-921258, S1-92521 and 111-52-25.
Genotypes S1-92747 and SHR02-P.4 had the highest increase and decrease in length of shoot at 30 compared to 20, respectively (Figure 1D). At 30, 23 genotypes produced longer shoot compared with the length of shoot at 20 , and three had a decreasing trend in the length of their shoot (Figure 1D). The seedling length of almost half sugar beet genotypes tested in this experiment decreased at 30, with 'SHR02-P.4' (34.42\%) showing the lowest amount of relative seedling length at 30 (Figure 1E).

\subsection{GREENHOUSE EXPERIMENT}

Sugar beet genotypes showed different performance under high temperature in greenhouse. The highest emergence percentage (88\%) was observed in 'S1-92521' with no significant difference from 'SHR01-P.12', 'S192128', fodder beet, 'S1-92685, S1-92039', 'SHR02-P.4' and '7233-P.29'. The lowest emergence percentage were observed in 'DR1-HSF14-P.35' (49\%), ‘O.T.607' (53\%), 'S1-92749' (56 \%), 'S1-92615' (57\%), '7112' (57\%) and '111-52-25’ (59\%) (Table 2).

The highest value of greenness index belonged to 'S1-92747' (34.99), whereas 'DR1-HSF14-P.35' (21.36) had the least value (Table 2). 'SB-33H-3', 'S1-92749', 'S192039' and 'S1-92750' indicated high values of greenness index with no significant difference from 'S1-92747'.

The maximum $F v / F m$ value belonged to 'DR1HSF14-P.35' (0.627), which had no significant difference from 20 of other genotypes, whereas 'SB26' (0.370), which was not significantly different from 'S1-92615' and 'SB-33-H-1', showed the lowest record of this trait (Table 2).

The minimum values of leaf, root, petiole and whole plant fresh mass were observed in 'S1-92006' (3.32 g), 'S1-92750' (0.60 g), 'S1-92006' (1.70 g) and 'S192006’ (5.72 g), respectively. 'DR1-HSF14-P.35' had the maximum value of the above-mentioned traits excluding root fresh mass whose maximum value belonged to 'S1-92521' (Table 2). According to the results, 'S192521' produced the most values of leaf, root and whole plant dry mass, and the highest petiole dry mass $(0.95$ g) belonged to 'SB33-H-2' (Table 2). The lowest values of leaf, root, shoot and total dry mass were attained for 'S1-92128' (0.25 g), 'S1-92006' (0.10 g), 'S1-92006' (0.13 g) and 'S1-92006' (0.52 g), respectively (Table 2). The highest leaf area was produced by 'S1-92039' (383.2 $\left.\mathrm{cm}^{2}\right)$ while the lowest value $\left(100.41 \mathrm{~cm}^{2}\right)$ was observed in 'S1-92747' and 'S1-92006' (Table 2).

A high variability of the $S D$ was observed among the sugar beet genotypes. The lowest $S D$ belonged to 'O.T.607' (68.37 stoma $\mathrm{mm}^{-2}$ ) (Table 3). On the contrary, genotypes with high $S D$ values (Table 3 ) were 

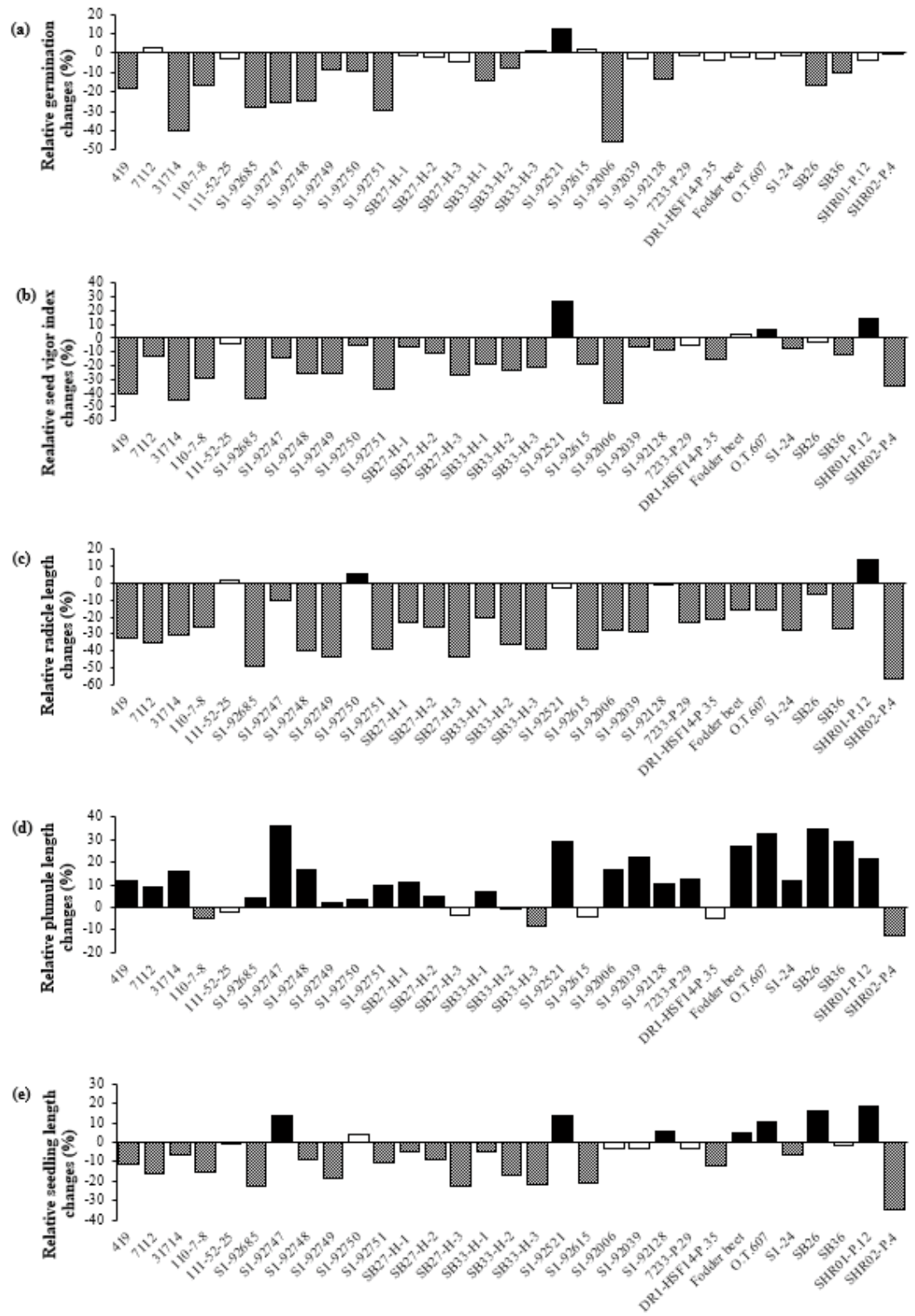

Figure 1: Relative germination (a), relative seed vigor index (b), relative seminal root length (c), relative shoot length (d) and relative seedling length (e) changes in sugar beet genotypes at 30 in comparison to 20. Solid fill columns, no fill columns (with $5 \%$ change) and pattern fill columns respectively indicate increasing, steady and decreasing trend of the traits at 30.

in the order of S1-92749 (223.74 stoma $\left.\mathrm{mm}^{-2}\right)$, SB27H-3 (211.33 stoma $\left.\mathrm{mm}^{-2}\right)$, SB26, 7112 and 419 (192.67 stoma $\left.\mathrm{mm}^{-2}\right)$.The least value of $E C D$ was obtained for 'O.T.607' (366.7 epiderm $\left.\mathrm{mm}^{-2}\right)$. '419', and 'SB26' (1274.1 and 1106.3 epiderm $\mathrm{mm}^{-2}$, respectively) showed the highest ECD amount with significant difference from other genotypes (Table 3 ). Sugar beet genotypes had significantly different $S P A$ values $(p<0.01)$. Genotypes 7233.P.29, 111-52-25, S1-92685, SB27-H-1, S1-92751, DR1-HSF14-P.35, fodder beet, S1-92039, O.T.607 and
SB33-H-2 showed higher SPA values compared to other genotypes. The least SPA value was observed in 'SB26' $\left(31 \mu \mathrm{m}^{2}\right)$ (Table 3). The highest and the lowest SPAI was observed for 'S1-92749' (0.742\%) and 'S1-92750' $(0.260 \%)$, respectively (Table 3$)$.

There was a significant difference $(p<0.01)$ in $A n$ between the first and the last ranks of sugar beet genotypes) (Table 3). Genotypes S1-92685 $\left(15.24 \mathrm{mmol} \mathrm{m}^{-2} \mathrm{~s}^{-1}\right)$ and S1-92748 $\left(14.57 \mathrm{mmol} \mathrm{m}^{-2} \mathrm{~s}^{-1}\right)$ showed the highest values of $A n$ and were significantly 


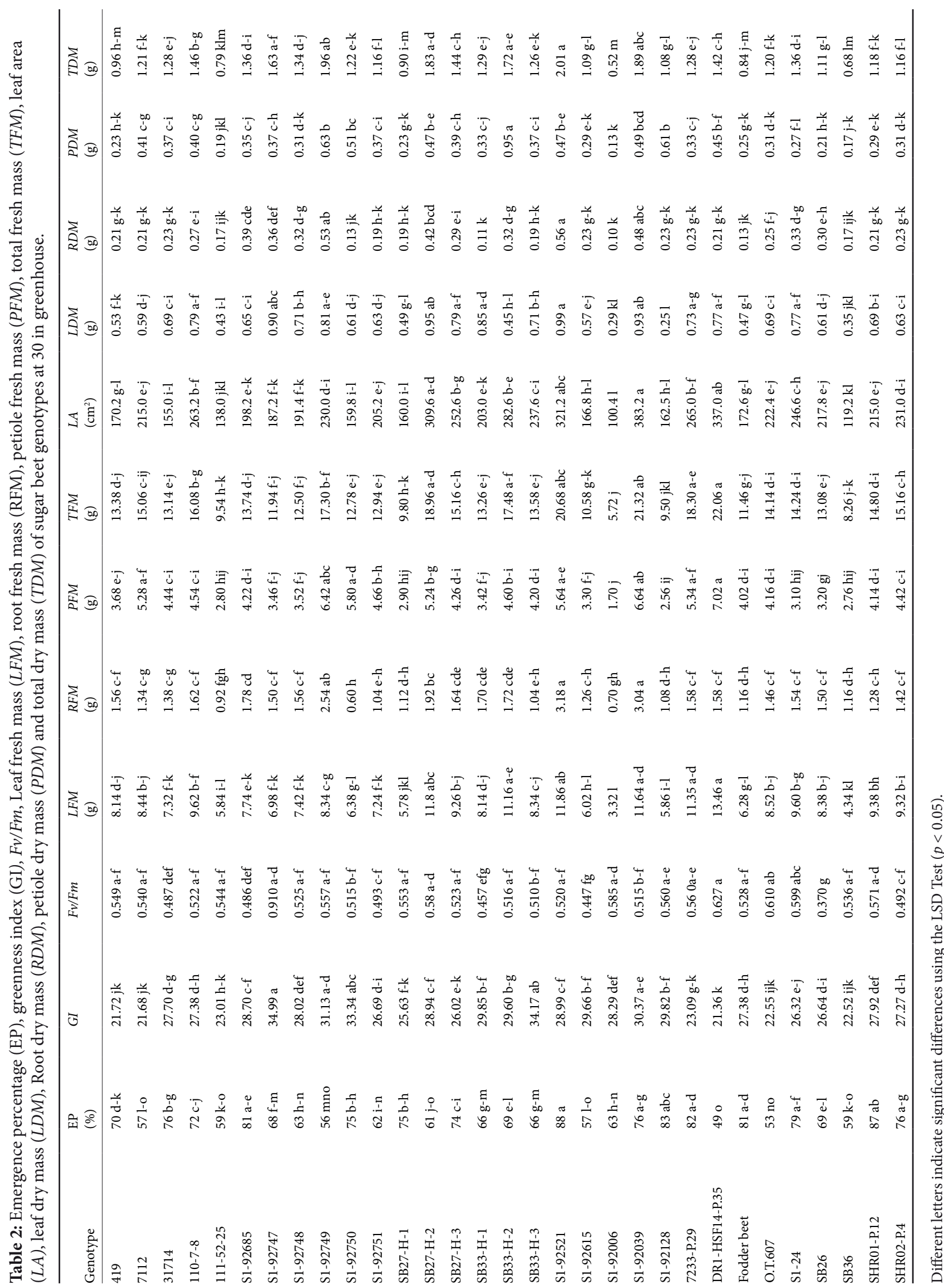




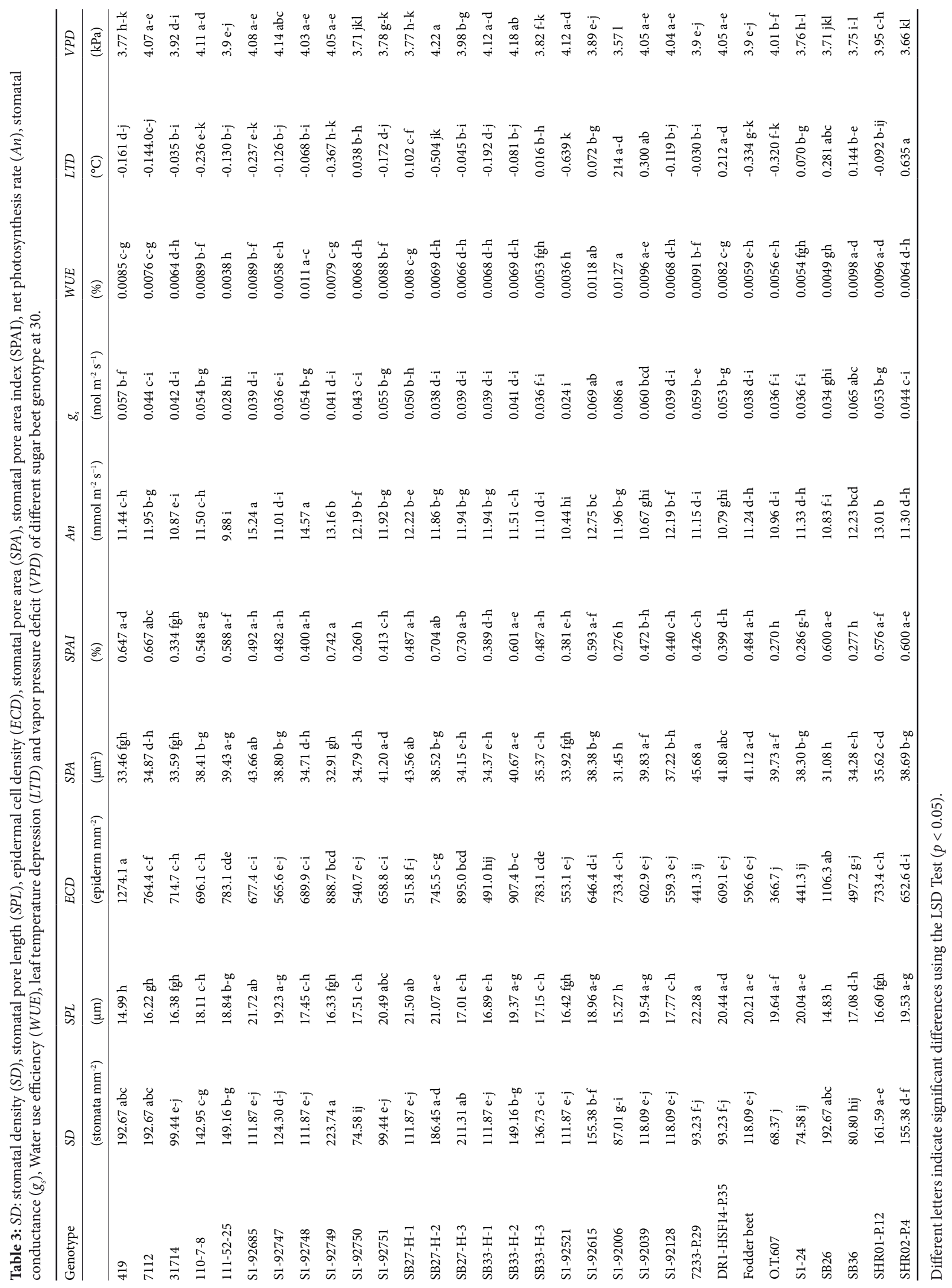


different from other genotypes at 30 regarding this trait (Table 3). The lowest amount of $A n$ was obtained for '111-52-25' (29.65 mmol m $\left.\mathrm{m}^{-2} \mathrm{~s}^{-1}\right)$. Stomatal conductance $\left(g_{s}\right)(p<0.001)$ of 'S1-92006' and 'S1-92615' (0.09 and $0.07 \mathrm{~mol} \mathrm{~m}^{-2} \mathrm{~s}^{-1}$, respectively) indicated the highest values and the minimum level of this trait was related to 'S1-92521' $\left(0.02 \mathrm{~mol} \mathrm{~m}^{-2} \mathrm{~s}^{-1}\right)$, with no significant difference from 18 of other genotypes (Table 3). The best WUE was observed in 'S1-92006' (0.0130\%) which had no significant difference from 'S1-92615', 'S1-92748', 'SB36', 'SHR01-P.12', and 'S1-92039'. On the other hand, the minimum WUE value belonged to 'S1-92521' (0.0036\%) and '111-52-25' (0.0038\%) (Table 3). 'SHR02-P.4' (0.635) produced the highest value of $L T D$. The least value for $L T D$ was obtained from 'S1-92521' (-0.639) (Table 3). Also in case of VPD, 'S192006' (3.57 kPa) and 'SB27-H-2' (4.22 kPa) had the highest and the lowest values, respectively (Table 3).

In order to have a better assessment of sugar beet genotypes based on important measured traits, the PCA was performed. The PCA revealed that two first components together accounted for $56.82 \%$ (38.23\% and $18.59 \%$, respectively) (Figure 2). Genotypes placed in the upper quarter on the right (S1-92039, DR1-HSF14-P.35, 7233-P.29, 110-7-8, S1-92749, S192685, 7112, SB27-H2 and SB33-H-2) had a high leaf area, total fresh mass, total dry mass, Fv/Fm and greenness index. On the other hand, genotypes placed in the upper quarter on the left (S1-92006, S1-92615, S1-92748, SHR01-P.12, SB36, S1-92751 and 419) had high values of $L T D, W U E, g_{s}$ and $A n$. Also it was revealed that leaf area, total fresh mass and total dry mass were not related to $W U E, g_{s}$ and $A n$. However, $\mathrm{Fv} / \mathrm{Fm}$ was positively related to all of these six traits.

\section{DISCUSSION}

This study was conducted to determine the tolerant genotypes of sugar beet in high temperature, as well as investigating the suitable criteria for screening tolerant genotypes. According to the results, in laboratory experiment, 'S1-92521', '111-52-25', 'SHR01P.12', 'O.T. 607', fodder beet, '7233-P.29' and 'SB26' demonstrated a better performance, compared to the other genotypes, almost in all traits in high temperature (Figure 1). Records of 'S1-92521', '111-52-25' and 'SHR01-P.12', in 30 were higher than those in 20, or did not change significantly (Figure 1). Specifically, all measured traits of 'S1-92521' showed higher records in 30 except seminal root length which did not change significantly. Similarly, except germination percentage, which did not change significantly, all traits of 'SHR01-P.12' improved in 30 compared with 20. There was not a significant change in any of the measured traits of '111-52-25' either. Genotypes O.T. 607, fodder beet, 7233-P.29 and SB26 performed well in all of the traits, too, except in the case of seminal root length which decreased in 30. In 'SB26', a decline in germination percentage was observed as well which can be compensated through planting more seeds. Genotypes with poor performance in laboratory experiment included 110-7-8, SB33-H2 and SHR02-P.4 (Figure 1). In most of the genotypes, seminal root length was negatively affected by heat stress, but concerning the whole seedling, this loss was, to some ex-

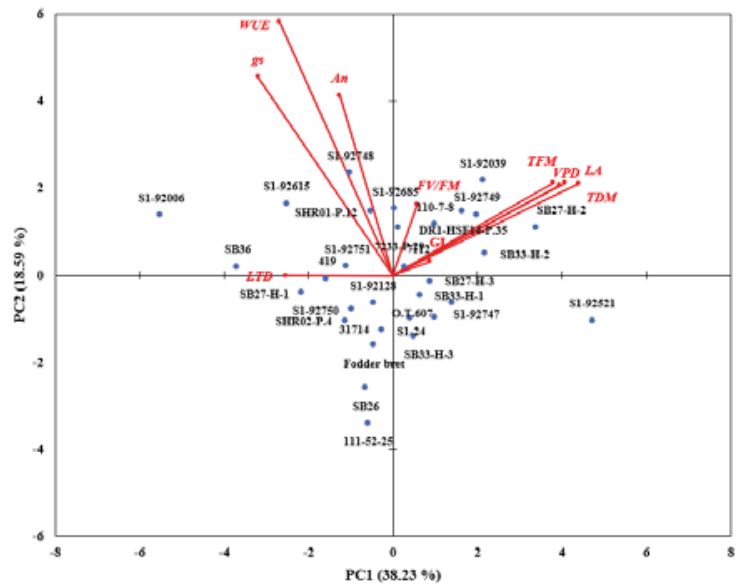

Figure 2: Biplot of the first and second principal component (PC) axes for greenness index (GI), leaf area (LA), leaf temperature depression $(L T D)$, net photosynthesis $(A n)$, photochemical efficiency of PSII $(F v / F m)$, stomatal conductance $\left(g_{s}\right)$, total dry mass $(T D M)$, total fresh mass (TFM) and water use efficiency (WUE) traits on sugar beet genotypes at 30. 
tent, compensated by increasing shoot length under high temperature (Figures 1C, 1D, 1E).

According to the results, two of the traits could be good criteria for screening tolerant genotypes to high temperature, seed vigor index and seminal root length. Genetically difference among the genotypes is a criteria to select a trait as a screening tool for stress tolerance (El-Hendawy et al., 2007). In the present study, by increasing the temperature, high differences among the genotypes were observed regarding seed vigor index and seminal root length (Figures 1B, 1C). In other words, almost all of the genotypes showed decreased records under heat stress, and just a few of them could show an increase or maintain without a significant change (Figures 1B, 1C). At this point, by having a more precise look, it can be seen that seed vigor index could be a better screening criteria rather seminal root length. Because genotypes which showed a better or unchanged seed vigor, generally had a good record in other measured traits in the laboratory experiment, too (like '7233-P.29' and 'O.T.607'), but this was not observed in the case of genotypes with a better or unchanged seminal root length (like 'S1-92750' and 'S1-92128') (Figure 1). Seed vigor index has been considered as a screening criteria in previous studies, too (ISTA, 2014). Seed germination factors and seedling properties have been considered as evaluation criteria in breeding programs that worked on environmental stresses such as drought stress (Sadeghian \& Yavari, 2004).

In greenhouse experiment, high amounts of leaf area, total fresh mass and total dry mass which were accounted for plant yield, were observed in 'S1-92521', 'S1-92039', 'SB33-H-2' and 'SB27-H2' (Table 2). Two other genotypes, S1-92747 and S1-92749, also showed high records for total dry mass and greenness index as well as quantum efficiency of PSII (Table 2, Figure 2). The potential of multivariate analysis technique such as PCA for the identification of tolerant genotypes to environmental stress has been shown in different crops such as rice (Cha-um et al., 2009), sugarcane (Cha-um et al., 2012), tomato (Juan et al., 2005), peanut (Liu et al., 2012) and soybean (Shelke et al., 2017). PCA identifies the probable grouping and establishment of relationships among variables (Martínez-Calvo et al., 2008; Sarabi et al., 2016). Regards lack of significant relationship between stomatal indices and gas exchange parameters maybe due to small number of samples (McElwain et al., 2016), we did not use stomatal characteristics in PCA. According to the PCA analysis, WUE and $g_{s}$ produced the most variance among the genotypes, and the least was related to greenness index and Fv/Fm (Figure 2). Furthermore, there was a positive relationship among total dry mass, total fresh mass, leaf area, greenness index and Fv/Fm (Figure 2). This implies that with more quantum efficiency of PSII, indicating less stress inside the plants, photosynthesis got more efficient, and consequently more assimilate were produced. $F v /$ $F m$ had a positive relationship with WUE, $g_{s}$ and $A n$, as well, indicating that more tolerance caused the net photosynthesis to rise (Figure 2). There is a positive relationship between $g_{s}$ and $A n$, showing that increasing stomatal conductance leads the $A n$ to rise (Urban et al., 2017). Stomatal conductance and $A_{n}$, did not show much relation with the yield parts of the plants, total dry mass and leaf area which could be because of the fact that these traits were measured instantaneously. In
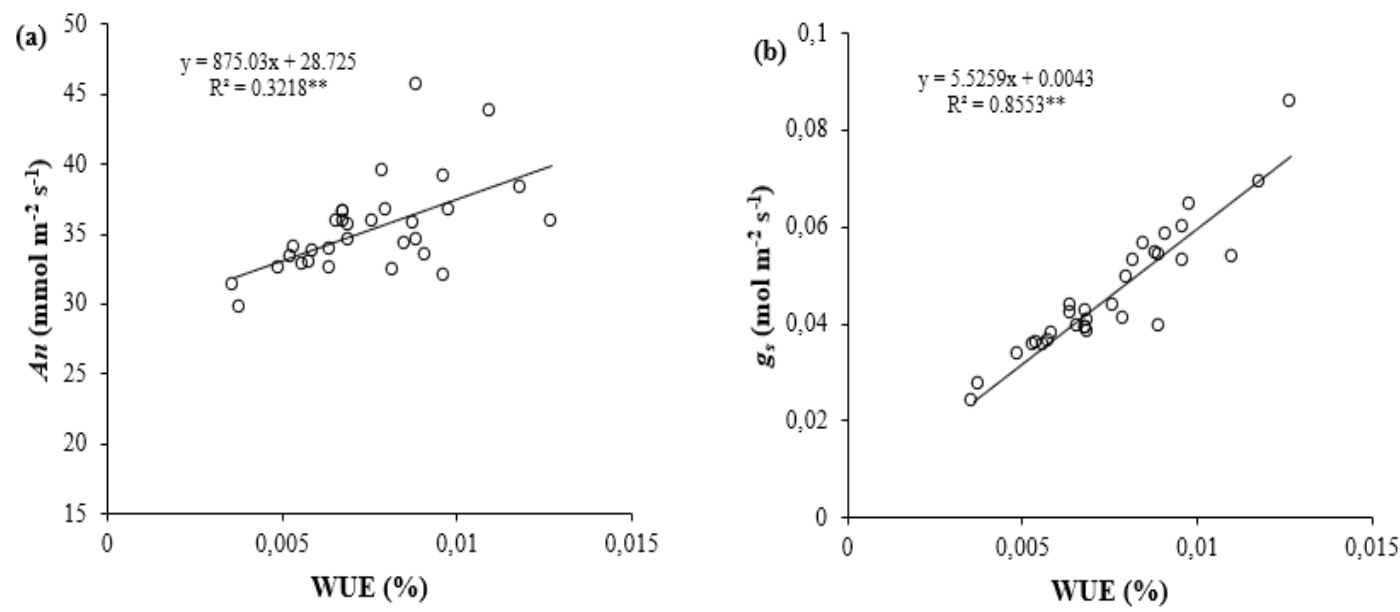

Figure 3: Relationship between $W U E$ and $A n(\mathbf{a})$ and $g s(\mathbf{b})$ in sugar beet genotypes $(\mathrm{n}=31) .{ }^{* *}$ indicate significant correlation at $p<0.05$ and 0.01 , respectively 
addition, it might be due to the increasing of transpiration under high temperature.

High VPD values of 'S1-92749', 'S1-92039', 'S192521' and 'SB27-H2' resulted higher total dry mass and leaf area; while, the least values of mentioned traits observed from 'S1-92006' and 'SB36' (Figure 2). Difference between the leaf and air temperatures (LTD) showed a negative relationship with yield parameters and also with VPD and a positive relationship with WUE, $g_{s}$ and $A n$ (Figure 3). This indicates that under high temperature, tolerant plants could maintain their stomata open resulting in cooling the leaves as a consequence of transpiration. Stomatal conductance to $\mathrm{CO}_{2}$ is strictly proportional to stomatal conductance to water (Gilbert et al., 2011). Gas exchange reaction to temperature was related to the interaction effect of some parameters like internal plant water status and VPD (Chaves, 1991). In addition, it has been mentioned that high temperature causes rising in $g_{s}$ (Killi et al., 2017). By increasing $V P D$, we witness an increase in stomatal conductance and leaf transpiration and consequently the mobility of water and nutrient in the plant (Caird et al., 2007). It has been well established that plants regulate rates of transpiration and photosynthesis in parallel, maintaining a balance between $g_{s}$ and $A n$ (Lawson et al., 2011). High positive correlation between canopy temperature depression and stomatal conductance has been observed in sugar beet (Mohammadian et al., 2001; Fukuoka, 2005). Under stress-free conditions the water transpired by the plants evaporates and cools the leaves (González-Dugo et al., 2006; Schauberger et al., 2017). In the present study, plants could maintain their transpiration because of the VPD and because the plants were not in shortage of water, as sufficient water was supplied for them. However, LTD of sugar beet genotypes was varied (Table 3 ). It was clear that sugar beet genotypes had different ability for cooling their leaves under high temperature.

In order to choose a screening criteria for heat tolerance in the sugar beet genotypes, the level of reaction to heat stress should be taken into consideration, as it was done in the laboratory experiment. High reaction intensities among the genotypes were observed in leaf area, total dry mass, $g_{s}$, An and LTD among which the first two traits need destructive harvest most of the time, so it is better not to choose them as criteria. Stomatal conductance $\left(g_{s}\right)$ and net photosynthetic rate $(A n)$ are not suitable either, because according to the PCA, they were not related to the yield parameters like total dry mass (Figure 2). Leaf temperature depression (LTD), however, could be considered as a screening criteria for heat tolerance, because it does not show the two weakness point mentioned above. Temperature difference between leaves and air has been considered as a screening criteria in previous studies as well (Reynolds et al., 2009). Canopy temperature depression was selected as a suitable screening tool for selecting drought-tolerance cultivars of wheat, because there was a genotypic variation for it, and also it was directly correlated with grain yield (Thapa et al., 2018). Quantum efficiency of PSII $(\mathrm{Fv} / \mathrm{Fm})$ could be considered as a good screening criterion for heat tolerance, because it was positively related to $g_{s}, A_{n}, W U E$ and yield parameters (Figure 2). Quantum efficiency of PSII $(F v / F m)$ has been introduced as a tool for early detection of heat (Zhou et al., 2015) and drought stress (Mohammadian et al., 2003). It was observed that $F v / F m$, shoot fresh mass, shoot dry mass and root dry mass of tomato genotypes decreased under heat stress conditions (Zhou et al., 2015). Also, Fv/ Fm had decreased in sugar beet by drought stress (Mohammadian et al., 2003). In addition, possibility of using biomass, canopy temperature depression, greenness index and $F v / F m$ for precise screening in heat-tolerant wheat genotypes has been proved (Joshi et al., 2007; Nagar et al., 2015).

A similarity was observed between the performance of some genotypes under high temperature in laboratory and that in greenhouse. Genotype S1-92521 showed a good performance in high temperature in both experiments in all traits (Figure 2 and Table 2 and $3)$. On the other hand, 'SB-27-H-1', 'S1-92006' and '111$52-25$ ' performed poorly in both laboratory and greenhouse experiments, especially in yield traits, leaf area and total dry mass. However, other genotypes did not show any noticeable similarity in their reaction to heat stress between laboratory and greenhouse experiments.

\section{CONCLUSION}

The present study investigated the sugar beet genotypes behavior under high temperature condition as well as identifying good screening tools at germination and early growth stages (4-6 leave stage). A high variation was observed among the genotypes in the present study, which is a valuable feature for breeding programs. Based on important traits, 'S1-92039', 'S1-92521', 'SB33-H-2', 'S1-92747', 'S1-92749' and 'SB27-H-2' were tolerant genotypes to high temperature in greenhouse. The only genotype which showed a good tolerance in both laboratory and greenhouse experiments, was S192521. Three genotypes, 110-7-8, SB33-H3, and SHR02P.4, did not perform well in neither of the two experiments. So, in general, except for 'S1-92521', we could not say the genotypes which performed well in laboratory could also tolerate high temperature in greenhouse. In 
laboratory experiment, seed vigor index was chosen as a good screening tool for selecting heat-tolerant genotypes. In greenhouse, LTD and Fv/Fm were considered as beneficial non-destructive screening tools to find tolerant sugar beet genotypes to high temperature at early growth stages.

\section{ACKNOWLEDGEMENTS}

This research was supported by Tarbiat Modares University and Sugar Beet Seed Institute of Iran.

\section{REFERENCES}

Agrawal, R. L. (2003). Seed technology. Pub. Co. Pvt. Ltd. New Delhi. India.

Arx, G., Graf Pannatier, E., Thimonier, A., and Rebetez, M. (2013). Microclimate in forests with varying leaf area index and soil moisture: potential implications for seedling establishment in a changing climate. Journal of Ecology, 101(5), 1201-1213. https://doi.org/10.1111/13652745.12121

Ashraf, M., Saeed, M. M., and Qureshi, M. J. (1994). Tolerance to high temperature in cotton (Gossypium hirsutum L.) at initial growth stages. Environmental and Experimental Botany, 34(3), 275-283. https://doi.org/10.1016/00988472(94)90048-5

Baalbaki, R., Elias, S., Marcos-Filho, J., and McDonald, M. B. (2009). Seed vigor testing handbook. Contribution No. 32 to the handbook on seed testing. Assoc. Offic. Seed Anal., Ithaca, New York.

Bafeel, S. O. (2014). Physiological parameters of salt tolerance during germination and seedling growth of Sorghum bicolor cultivars of the same subtropical origin. Saudi Journal of Biological Sciences, 21(4), 300-304. https://doi. org/10.1016/j.sjbs.2014.05.005

Balota, M., Payne, W. A., Evett, S. R., and Peters, T. R. (2008). Morphological and physiological traits associated with canopy temperature depression in three closely related wheat lines. Crop Science, 48(5), 1897-1910. https://doi. org/10.2135/cropsci2007.06.0317

Beckage, B., and Clark, J. S. (2003). Seedling survival and growth of three forest tree species: the role of spatial heterogeneity. Ecology, 84(7), 1849-1861. https://doi. org/10.1890/0012-9658(2003)084[1849:SSAGOT]2.0. $\mathrm{CO} ; 2$

Bin, Z., Qingya, W., and Canming, T. (2008). Anatomic analysis on heterosis in three transgenic bt pest-resistant hybrid cotton (G. hirsutum L.). Acta Agronomica Sinica.

Buchner, O., Stoll, M., Karadar, M., Kranner, I., and Neuner, G. (2015). Application of heat stress in situ demonstrates a protective role of irradiation on photosynthetic performance in alpine plants. Plant, Cell \& Environment, 38(4), 812-826. https://doi.org/10.1111/pce.12455

Caird, M. A., Richards, J. H., and Donovan, L. A. (2007).
Nighttime stomatal conductance and transpiration in C3 and C4 plants. Plant Physiology, 143(1), 4-10. https://doi. org/10.1104/pp.106.092940

Carpýcý, E. B., Celýk, N., and Bayram, G. (2009). Effects of salt stress on germination of some maize (Zea mays L.) cultivars. African Journal of Biotechnology, 8(19).

Cha-um, S., Boriboonkaset, T., Pichakum, A., and Kirdmanee, C. (2009). Multivariate physiological indices for salt tolerance classification in indica rice (Oryza sativa L. spp. indica). General and Applied Plant Physiology, 35(1/2), 75-87.

Cha-um, S., Chuencharoen, S., Mongkolsiriwatana, C., Ashraf, M., and Kirdmanee, C. (2012). Screening sugarcane (Saccharum sp.) genotypes for salt tolerance using multivariate cluster analysis. Plant Cell, Tissue and Organ Culture (PCTOC), 110(1), 23-33. https://doi.org/10.1007/s11240012-0126-9

Chaves, M. M. (1991). Effects of water deficits on carbon assimilation. Journal of Experimental Botany, 42(1), 1-16. https://doi.org/10.1093/jxb/42.1.1

El-Hendawy, S. E., Hu, Y., and Schmidhalter, U. (2007). Assessing the suitability of various physiological traits to screen wheat genotypes for salt tolerance. Journal of Integrative Plant Biology, 49(9), 1352-1360. https://doi.org/10.1111/ j.1744-7909.2007.00533.x

El-Kholi, M. M. (2008). Sugar Crops Research Institute, Giza (Egypt): A Profile. Sugar Tech, 10(3), 189-196. https://doi. org/10.1007/s12355-008-0036-7

Fahad, S., Bajwa, A. A., Nazir, U., Anjum, S. A., Farooq, A., Zohaib, A., and Ihsan, M. Z. (2017). Crop production under drought and heat stress: plant responses and management options. Frontiers in Plant Science, 8, 1147. https://doi. org/10.3389/fpls.2017.01147

Fukuoka, M. (2005). Improvement of a method for measuring canopy temperature in field crops using an infrared thermograph. Hokkaido University, Sapporo, Japan, 1-45.

Gilbert, M. E., Zwieniecki, M. A., and Holbrook, N. M. (2011). Independent variation in photosynthetic capacity and stomatal conductance leads to differences in intrinsic water use efficiency in 11 soybean genotypes before and during mild drought. Journal of Experimental Botany, 62(8), 2875-2887. https://doi.org/10.1093/jxb/erq461

González-Dugo, M. P., Moran, M. S., Mateos, L., and Bryant, R. (2006). Canopy temperature variability as an indicator of crop water stress severity. Irrigation Science, 24(4), 233. https://doi.org/10.1007/s00271-005-0022-8

Gratani, L., Pesoli, P., Crescente, M. F., Aichner, K., and Larcher, W. (2000). Photosynthesis as a temperature indicator in Quercus ilex L.. Global and Planetary Change, 24(2), 153163. https://doi.org/10.1016/S0921-8181(99)00061-2

Grzesiak, S., Grzesiak, M. T., Filek, W., and Stabryła, J. (2003). Evaluation of physiological screening tests for breeding drought resistant triticale (x Triticosecale Wittmack). Acta Physiologiae Plantarum, 25(1), 29-37. https://doi. org/10.1007/s11738-003-0033-0

Gutierrez, M., Reynolds, M. P., Raun, W. R., Stone, M. L., and Klatt, A. R. (2010). Spectral water indices for assessing yield in elite bread wheat genotypes under well-irrigated, water-stressed, and high-temperature conditions. Crop 
Science, 50(1), 197-214. https://doi.org/10.2135/cropsci2009.07.0381

Havaux, I. (1993). Rapid photosynthetic adaptation to heat stress triggered in potato leaves by moderately elevated temperatures. Plant, Cell \& Environment, 16(4), 461-467. https://doi.org/10.1111/j.1365-3040.1993.tb00893.x

ISTA International Seed Testing Association (2014). Seed Vigour Testing. International Rules for Seed Testing, Zurich, Switzerland.

ISTA International Seed Testing Association (2010). International rules for seed testing, edition. 2010. BassersdorfSwitzerland. The International Seed Testing Association.

Joshi, A. K., Mishra, B., Chatrath, R., Ferrara, G. O., and Singh, R. P. (2007). Wheat improvement in India: present status, emerging challenges and future prospects. Euphytica, 157(3), 431-446. https://doi.org/10.1007/s10681-0079385-7

Juan, M., Rivero, R. M., Romero, L., and Ruiz, J. M. (2005). Evaluation of some nutritional and biochemical indicators in selecting salt-resistant tomato cultivars. Environmental and Experimental Botany, 54(3), 193-201. https:// doi.org/10.1016/j.envexpbot.2004.07.004

Karandish, F., Mousavi, S. S., and Tabari, H. (2017). Climate change impact on precipitation and cardinal temperatures in different climatic zones in Iran: analyzing the probable effects on cereal water-use efficiency. Stochastic Environmental Research and Risk Assessment, 31(8), 21212146. https://doi.org/10.1007/s00477-016-1355-y

Killi, D., Bussotti, F., Raschi, A., and Haworth, M. (2017). Adaptation to high temperature mitigates the impact of water deficit during combined heat and drought stress in C3 sunflower and C4 maize varieties with contrasting drought tolerance. Physiologia Plantarum, 159(2), 130-147. https://doi.org/10.1111/ppl.12490

Kumar, M., Govindasamy, V., Rane, J., Singh, A. K., Choudhary, R. L., Raina, S. K., ... and Singh, N. P. (2017). Canopy temperature depression (CTD) and canopy greenness associated with variation in seed yield of soybean genotypes grown in semi-arid environment. South African Journal of Botany, 113, 230-238. https://doi.org/10.1016/j. sajb.2017.08.016

Lawson, T., von Caemmerer, S., and Baroli, I. (2010). Photosynthesis and stomatal behaviour. In: Progress in Botany 72 (pp. 265-304). Springer, Berlin, Heidelberg.

Liu, X., and Huang, B. (2008). Photosynthetic acclimation to high temperatures associated with heat tolerance in creeping bentgrass. Journal of Plant Physiology, 165(18), 1947-1953. https://doi.org/10.1016/j.jplph.2008.05.001

Liu, Y. H., Shen, Y., Chen, Z. D., Wang, Z. F., and Yan, W. (2012). Identification of salt tolerance in peanut varieties/lines at the germination stage. Chinese Journal of Oil Crop Sciences, 34(2), 168-173.

Marias, D. E., Meinzer, F. C., and Still, C. (2017). Impacts of leaf age and heat stress duration on photosynthetic gas exchange and foliar nonstructural carbohydrates in Coffea arabica. Ecology and Evolution, 7(4), 1297-1310. https:// doi.org/10.1002/ece3.2681

Martínez-Calvo, J., Gisbert, A. D., Alamar, M. C., Hernandorena, R., Romero, C., Llácer, G., and Badenes, M. L.
(2008). Study of a germplasm collection of loquat (Eriobotrya japonica Lindl.) by multivariate analysis. Genetic Resources and Crop Evolution, 55(5), 695-703. https://doi. org/10.1007/s10722-007-9276-8

Maxwell, K., and Johnson, G. N. (2000). Chlorophyll fluorescence-a practical guide. Journal of Experimental Botany, 51(345), 659-668. https://doi.org/10.1093/ jexbot/51.345.659

McElwain, J. C., Yiotis, C., and Lawson, T. (2016). Using modern plant trait relationships between observed and theoretical maximum stomatal conductance and vein density to examine patterns of plant macroevolution. New Phytologist, 209(1), 94-103. https://doi.org/10.1111/nph.13579

Miner, G. L., Bauerle, W. L., and Baldocchi, D. D. (2017). Estimating the sensitivity of stomatal conductance to photosynthesis: a review. Plant, Cell \& Environment, 40(7), 12141238. https://doi.org/10.1111/pce.12871

Mohammadian, R., Khoyi, F. R., Rahimian, H., Moghadam, M., Ghassemi-Golezani, K., and Sadeghian, S. Y. (2010). The effects of early season drought on stomatal conductance, leaf-air temperature difference and proline accumulation in sugar beet genotypes. Journal of Agricultural Science and Technology, 3, 181-192.

Mohammadian, R., Rahimian, H., Moghaddam, M., and Sadeghian, S. Y. (2003). The effect of early season drought on chlorophyll a fluorescence in sugar beet (Beta vulgaris L.). Pakistan Journal of Biological Sciences (Pakistan).

Mohammadian, R., Moghaddam, M., Rahimian, H., and Sadeghian, S. Y. (2005). Effect of early season drought stress on growth characteristics of sugar beet genotypes. Turkish Journal of Agriculture and Forestry, 29(5), 357-368.

Munns, R., and Tester, M. (2008). Mechanisms of salinity tolerance. Annual Review of Plant Biology, 59, 651-681. https://doi.org/10.1146/annurev.arplant.59.032607.092911

Murakami, Y., Tsuyama, M., Kobayashi, Y., Kodama, H., and Iba, K. (2000). Trienoic fatty acids and plant tolerance of high temperature. Science, 287(5452), 476-479.

Nagar, S., Singh, V. P., Arora, A., Dhakar, R., and Ramakrishnan, S. (2015). Assessment of terminal heat tolerance ability of wheat genotypes based on physiological traits using multivariate analysis. Acta Physiologiae Plantarum, 37(12), 257. https://doi.org/10.1007/s11738-015-2017-2

Ober, E. S., and Rajabi, A. (2010). Abiotic stress in sugar beet. Sugar Tech, 12(3-4), 294-298. https://doi.org/10.1007/ s12355-010-0035-3

Pandey, M., and Penna, S. (2017). Time course of physiological, biochemical, and gene expression changes under short-term salt stress in Brassica juncea L. The Crop Journal, 5(3), 219-230. https://doi.org/10.1016/j.cj.2016.08.002

Pinto, R. S., Reynolds, M. P., Mathews, K. L., McIntyre, C. L., Olivares-Villegas, J. J., and Chapman, S. C. (2010). Heat and drought adaptive QTL in a wheat population designed to minimize confounding agronomic effects. Theoretical and Applied Genetics, 121(6), 1001-1021. https://doi. org/10.1007/s00122-010-1351-4

Reynolds, M., Manes, Y., Izanloo, A., and Langridge, P. (2009). Phenotyping approaches for physiological breeding and gene discovery in wheat. Annals of Applied Biol- 
ogy, 155(3), 309-320. https://doi.org/10.1111/j.17447348.2009.00351.x

Reynolds, M. P., Balota, M., Delgado, M. I. B., Amani, I., and Fischer, R. A. (1994). Physiological and morphological traits associated with spring wheat yield under hot, irrigated conditions. Functional Plant Biology, 21(6), 717-730. https://doi.org/10.1071/PP9940717

Rizhsky, L., Liang, H., and Mittler, R. (2002). The combined effect of drought stress and heat shock on gene expression in tobacco. Plant Physiology, 130(3), 1143-1151. https:// doi.org/10.1104/pp.006858

Sadeghian, S.Y. and Yavari, N., 2004. Effect of water-deficit stress on germination and early seedling growth in sugar beet. Journal of Agronomy and Crop Science, 190(2), pp.138-144.

Sarabi, B., Bolandnazar, S., Ghaderi, N., and Tabatabaei, S. J. (2016). Multivariate analysis as a tool for studying the effects of salinity in different melon landraces at germination stage. Notulae Botanicae Horti Agrobotanici Cluj-Napoca, 44(1), 264-271. https://doi.org/10.15835/nbha44110234

Schauberger, B., Archontoulis, S., Arneth, A., Balkovic, J., Ciais, P., Deryng, D., and Pugh, T. A. (2017). Consistent negative response of US crops to high temperatures in observations and crop models. Nature Communications, 8, 13931. https://doi.org/10.1038/ncomms13931

Sharma, D. K., Andersen, S. B., Ottosen, C. O., and Rosenqvist, E. (2015). Wheat cultivars selected for high Fv/Fm under heat stress maintain high photosynthesis, total chlorophyll, stomatal conductance, transpiration and dry matter. Physiologia Plantarum, 153(2), 284-298. https://doi. org/10.1111/ppl.12245

Shelke, D. B., Pandey, M., Nikalje, G. C., Zaware, B. N., Suprasanna, P., and Nikam, T. D. (2017). Salt responsive physiological, photosynthetic and biochemical attributes at early seedling stage for screening soybean genotypes. Plant Physiology and Biochemistry, 118, 519-528. https:// doi.org/10.1016/j.plaphy.2017.07.013

Silva, E. N., Ferreira-Silva, S. L., de Vasconcelos Fontenele, A., Ribeiro, R. V., Viégas, R. A., and Silveira, J. A. G. (2010). Photosynthetic changes and protective mechanisms against oxidative damage subjected to isolated and combined drought and heat stresses in Jatropha curcas plants. Journal of Plant Physiology, 167(14), 1157-1164. https:// doi.org/10.1016/j.jplph.2010.03.005

Thapa, S., Jessup, K. E., Pradhan, G. P., Rudd, J. C., Liu, S., Mahan, J. R., and Xue, Q. (2018). Canopy temperature depression at grain filling correlates to winter wheat yield in the US Southern High Plains. Field Crops Research, 217, 11-19. https://doi.org/10.1016/j.fcr.2017.12.005

TeKrony, D. M., and Egli, D. B. (1991). Relationship of seed vigor to crop yield: a review. Crop Science, 31(3), 816-822. https://doi.org/10.2135/cropsci1991.0011183X003100030 $054 \mathrm{x}$

Urban, J., Ingwers, M. W., McGuire, M. A., and Teskey, R. O. (2017). Increase in leaf temperature opens stomata and decouples net photosynthesis from stomatal conductance in Pinus taeda and Populus deltoides $x$ nigra. Journal of experimental botany, 68(7), 1757-1767. https://doi. org/10.1093/jxb/erx052

Wang, D., Heckathorn, S. A., Barua, D., Joshi, P., Hamilton, E. W., and LaCroix, J. J. (2008). Effects of elevated CO2 on the tolerance of photosynthesis to acute heat stress in C3, C4, and CAM species. American Journal of Botany, 95(2), 165-176. https://doi.org/10.3732/ajb.95.2.165

Webber, H., Martre, P., Asseng, S., Kimball, B., White, J., Ottman, M., and Kassie, B. (2017). Canopy temperature for simulation of heat stress in irrigated wheat in a semiarid environment: A multi-model comparison. Field Crops Research, 202, 21-35. https://doi.org/10.1016/j. fcr.2015.10.009

Xu, Z. Z., and Zhou, G. S. (2005). Effects of water stress and high nocturnal temperature on photosynthesis and nitrogen level of a perennial grass Leymus chinensis. Plant and Soil, 269(1-2), 131-139. https://doi.org/10.1007/s11104004-0397-y

Xu, Z. Z., Zhou, G. S., and Shimizu, H. (2009). Effects of soil drought with nocturnal warming on leaf stomatal traits and mesophyll cell ultrastructure of a perennial grass. Crop Science, 49(5), 1843-1851. https://doi.org/10.2135/ cropsci2008.12.0725

Yang, H., Grassini, P., Cassman, K. G., Aiken, R. M., and Coyne, P. I. (2017). Improvements to the Hybrid-Maize model for simulating maize yields in harsh rainfed environments. Field Crops Research, 204, 180-190. https://doi. org/10.1016/j.fcr.2017.01.019

Zandalinas, S. I., Mittler, R., Balfagón, D., Arbona, V., and Gómez-Cadenas, A. (2018). Plant adaptations to the combination of drought and high temperatures. Physiologia Plantarum, 162(1), 2-12. https://doi.org/10.1111/ ppl.12540

Zheng, Y., Xu, M., Hou, R., Shen, R., Qiu, S., and Ouyang, Z. (2013). Effects of experimental warming on stomatal traits in leaves of maize (Zea may L.). Ecology and Evolution, 3(9), 3095-3111. https://doi.org/10.1002/ece3.674

Zhou, R., Yu, X., Kjær, K. H., Rosenqvist, E., Ottosen, C. O., and $\mathrm{Wu}, \mathrm{Z}$. (2015). Screening and validation of tomato genotypes under heat stress using Fv/Fm to reveal the physiological mechanism of heat tolerance. Environmental and Experimental Botany, 118, 1-11. https://doi.org/10.1016/j. envexpbot.2015.05.006 